\title{
PROFIL OSTEOBLAS DAN OSTEOKLAS TULANG ALVEOLAR PADA MODEL TIKUS DIABETES TAHAP AWAL DENGAN APLIKASIGAYA ORTODONTI YANG BERBEDA
}

\author{
Nuzulul Hikmah \\ Biomedik Fakultas Kedokteran Gigi Universitas Jember \\ Email : nuzulul.drg@gmail.com
}

\begin{abstract}
ABSTRAK
Orthodontic tooth movement is obtained through alveolar bone remodeling. Alveolar bone remodeling includes resorption process that played by osteoclasts and bone formed process that played by osteoblasts. Diabetes affects on orthodontic tooth movement. The magnitude of orthodontic force that applied in the early stages of diabetic conditions, would be a consideration of the alveolar bone remodeling process. The purpose of this study was to determine osteoblast and osteoclast profile in early stage of rat diabetic models with different orthodontic force application. 24 Wistar rats were divided into three groups of controls andthree groups of early stage of diabetic treatment with different orthodontic force application (10, 20, and 30 gramforce/grf). The results showed an increased of osteoclast numbers in early stage of diabetes and will be increased along with the increased of orthodontic force. The results also showed a decreased of osteoblast number in early stage of diabetes, but it would be increased along with the increased of orthodontic force.

Keywords: Osteoblast, osteoclast, diabetes, orthodontic force.
\end{abstract}

\section{PENDAHULUAN}

Perawatan ortodonti merupakan perawatan di bidang kedokteran gigi yang bertujuan untuk memperbaiki maloklusi pada gigi geligi. Pergerakan gigi pada perawatan ortodonti diperoleh melalui remodeling tulang alveolar dan jaringan periodontal sebagai respon terhadap adanya gaya mekanis (gaya ortodonti).

Aplikasi gaya ortodonti pada gigi geligi menyebabkan resorpsi tulang alveolar pada daerah tekanan di ligamenperiodontal, sedangkan daerah tarikan pada ligamen periodontal mengalami pembentukan tulang (Roberts-Harry dan Sandy, 2004).

Tulang secara konstan mengalami proses remodeling yang merupakan proses kompleks yang meliputi resorpsi dan pembentukan tulang. Remodeling tulang membutuhkan koordinasi dari tiga tipe sel yaitu osteosit, osteoblas dan osteoklas. Dengan pemberian gaya mekanis, osteosit berperan sebagai mekanosensor untuk mendeteksi perubahan aliran bone fluid dalam bone canaliculi, serta merespon-nya melalui sinyal transmisi menuju osteoblas sebagai syncytial process. Selanjutnya osteoblas menstimulasi diferensiasi osteoklas dan meresorpsi tulang (Wongdee dan Charoenphandhu, 2011).
Resorpsi dan pembentukan tulang alveolar selama pergerakan gigi secara ortodonti bergantung pada besar, arah dan lamanya pemberian gaya mekanis. Pemberian gaya mekanis yang berlebihan akan menekan jaringan periodontal, sehingga terjadi trombosis, kematian sel dan hyalinisasi (Meikle, 2006). Perubahan status metabolik dapat mengganggu remodeling tulang, yang dapat menyebabkan perbedaan tingkat pergerakan gigi (Verna et al., 2000). Oleh karena itu, diabetes dapat mempengaruhi pergerakan gigi secara ortodonti (Reichert et al., 2009.Diabetes mempengaruhi bone turnover, menyebabkan penurunan densitas mineral tulang, osteopenia, osteoporosis, keparahan penyakit periodontal (Rakel et al., 2008 dan Lappin et al., 2009).

Beberapa penelitian telah menjelaskan mekanisme perubahan remodeling tulang pada diabetes, salah satunya adalah penurunan pembentukan tulang sebagai hasil dari penurunan aktivitas osteoblas atau peningkatan apoptosis dari sel osteoblas (He et al., 2004). Faktor lain yang berkontribusi adalah peningkatan aktivitas resorpsi tulang (Liu et al., 2006). Diabetes/Hiperglikemia menginduksi polyol pathway, produksi advanced glycation end products (AGEs), 
reactive oxigen species (ROS) serta aktivasi protein kinase $C$ ( $\mathrm{PKC})$, yang berpengaruh langsung maupun tidak langsung terhadap remodeling jaringan periodontal dan bone loss (Graves et al., 2007).

Perawatan ortodonti pada kondisi diabetestahap awal diduga berpengaruh terhadap proses remodeling tulang alveolar. Aplikasi besarnya gaya ortodonti menjadi pertimbangan pada kondisi diabetes tahap awal, sehingga diharapkan tidak terjadi kerusakan tulang alveolar lebih lanjut serta terjadi pergerakan gigi secara optimal. Tujuan dari penelitian ini adalah untukmengetahui profil osteoklas dan osteoblas tulang alveolar pada model tikus diabetes tahap awal dengan aplikasi gaya ortodonti yang berbeda.

\section{BAHAN DAN METODE}

\section{Hewan Coba dan Sampel}

Hewan coba yang digunakan dalam penelitian ini adalah tikus putih (Rattus norvegicus) strain Wistar, yang diperoleh dari Laboratorium Farmakologi Fakultas Kedokteran Universitas Brawijaya Malang. Kriteria inklusi dalam penelitian ini adalah, (a) kondisi fisik tikus putih sehat dan tidak mengalami kelainan, (b) jenis kelamin jantan, (c) usia 4 bulan, (d) Berat badan 250-300 gram.Kriteria eksklusi, (a) tikus mengalami cacat atau kelainan, (b) tikus yang mati selama penelitian, (c) pada pemeriksaan kadar gula darah hari ke 3 belum menunjukkan tanda hiperglikemia.

Besar sampel dalam penelitian ini adalah sebanyak 24 ekor tikus (4 ekor tikus untuk setiap kelompok). Rancangan penelitian terdiridari, K1 (kontrol negatif, normal, tidak memakai alat ortodonti), K2 (kontrol positif diabetes awal, tidak memakai alat ortodonti), K3 (kontrol positif, normal, memakai alat ortodonti 30 grf), K4 (kondisi diabetes awal, memakai alat ortodonti gaya 10 grf), K5 (kondisi diabetes awal, memakai alat ortodonti gaya 20 grf), K6 (kondisi diabetes awal, memakai alat ortodonti gaya 30 grf). Penelitian dilakukan setelah mendapat persetujuan dari Komite Etik Fakultas Kedokteran Universitas Brawijaya Malang.

\section{Induksi Stratified Dose Streptozotocin (SD-} STZ) pada Hewan Coba

Setelah di aklimatisasi selama satu minggu, hewan coba ditimbang berat badannya, kemudian disuntikkan
Streptozotocin (Nacalai tesque inc. Kyoto Japan, code 32238-91) dengan dosis bertingkat secara intraperitoneum. Induksi dimulai dengan dosis $40 \mathrm{mg} / \mathrm{kgBB}, 35 \mathrm{mg} / \mathrm{kgBB}, 30$ $\mathrm{mg} / \mathrm{kgBB}, 25 \mathrm{mg} / \mathrm{kgBB}$ dan $20 \mathrm{mg} / \mathrm{KgBB}$ selama 5 hari berturut-turut. Hewan coba diinkubasi selama 7 hari, dan diobservasi kadar glukosa darahnya yang diambil dari vena ekor tikus. Tikus dengan diabetes ditandai dengan Kadar Glukosa Darah (KGD) $\geq 300$ mg/dl (Nurdiana et al., 1998).

\section{Desain, Pengukuran Gaya dan Pemasangan Alat Ortodonti}

Desain alat ortodonti yang aplikasikan pada hewan coba berupa kawatstainless steel 0,012 U (ClassOne Orthodontics, USA) dengan koil diameter $2 \mathrm{~mm}$, dan panjang lengan kawat $10 \mathrm{~mm}$. Ujung lengan kawat di pasang pada matrix band (Meba, Germany) berbentuk cincin dengan panjang 2 $\mathrm{mm}$ (Maulana et al., 2014). Besar gaya mekanis yang dibebankan sebesar 10, 20, dan 30 grf.Pengukuran gaya mekanis pada alat ortodonti menggunakan desain pemodelan dengan tool ANSYS ver.14 struktural, yang selanjutnya dikonfirmasi menggunakan alat pengukur tekanan (The Richmond Orthodontics Stress and Tension Gauge, Ormco, USA), yang diletakkan pada papan model ukur.

Hewan coba dianestesi menggunakan Ketamine $\mathrm{HCl}$ (Anasject) dengan dosis 10 $\mathrm{mg} / \mathrm{KgBB}$ secara intraperitoneum. Gigi insisif rahang atas di sebelah mesial dibentuk menggunakan metal strip (Biodiinamica, Brasil) sampai kedua gigi insisif rahang atas membentuk kesejajaran. Alat ortodonti dipasang pada gigi insisif rahang atas secara tegak lurus dengan sumbu gigi. Stabilisasi alat ortodonti menggunakan semen glass ionomer tipe IX (Fuji IX GC, Japan). Lama pemasangan alat ortodonti adalah 7 hari (Gambar 1). 


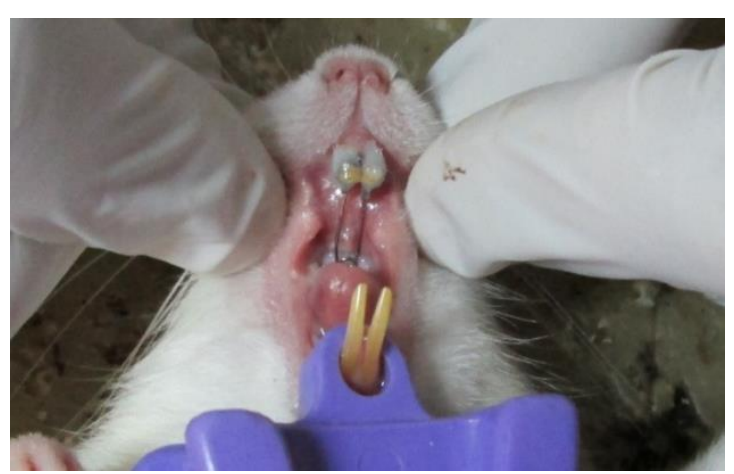

Gambar 1. Pemasangan Alat Ortodonti. Alat ortodonti dipasang pada gigi insisif rahang atas secara tegak lurus dengan sumbu gigi, serta sumbu alat ortodonti yang berimpit sejajar dengan garis median gigi.

\section{Prosedur Histologis}

Hewan coba dieutanasia menggunakan anestesi eter, alat ortodonti dilepas dan dilakukan pemotongan rahang atas pada regio kedua gigi insisif dengan menggunakan bur. Sampel di fiksasi menggunakan formalin $10 \%$ selama 24 jam, dekalsifikasi menggunakan EDTA $14 \%$ selama 30 hari, dilakukan dehidrasi, clearing, embedding parafin,sertapemotongan menggunakan mikrotom arah longitudinal dengan ketebalan 5 mikronuntuk prosedur pengecatan Hematoxylin Eosin (HE).

Dilakukan prosedur pewarnaan menggunakan HE untuk mengetahui gambaran histologis sel osteoblas dan osteoklas. Penghitungan sel osteoblas dan osteoklas dilakukan menggunakan mikroskop (Olympus

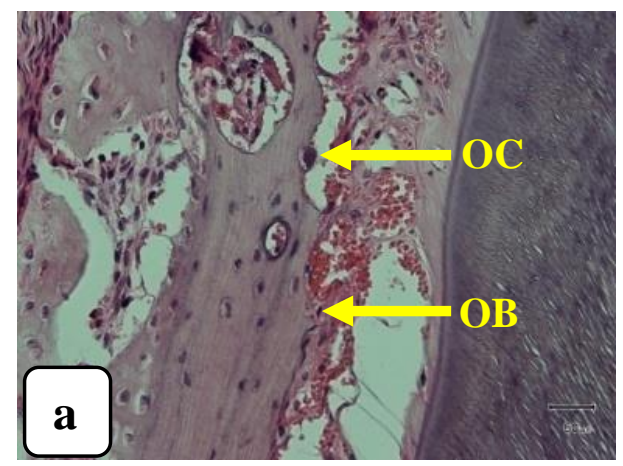

$B X-51)$ perbesaran $400 \mathrm{X}$ pada 4 potongan jaringan di 5 lapang pandang terpilih.

\section{Analisis Statistik}

Data hasil perhitungan meliputi ratarata jumlah osteoblas serta rata-rata jumlah osteoklas tulang alveolar pada daerah tekanan dan tarikan di ligamen periodontal. Analisis statistikmeliputi Uji ANOVA dan Uji tmenggunakan SPSS 20.0.

\section{HASIL}

Osteoblas

Sel osteoblas tulang alveolar dapat diamati pada daerah tekanan dan tarikan ligamen periodontal (Gambar 2). Rata-rata jumlah osteoblas di daerah tarikan lebih banyak dibandingkan daerah tekanan (Gambar 3a). Hasil uji ANOVA menunjukkan perbedaan yang bermakna pada kelompok K3K4-K5 $(p=0.00)$, di daerah tekanan dan tarikan. Hasil uji $t$ menunjukkan adanya perbedaan yang bermakna pada kelompok K1K2 $(p=0.00)$, di daerah tekanan dan dan tarikan.

\section{Osteoklas}

Sel osteoklas dapat diamati pada daerah tekanan dan tarikan ligamen periodontal (Gambar 2). Rata-rata jumlah osteoklas pada daerah tekanan lebih banyak dibandingkan pada daerah tarikan (Gambar 3b). Hasil uji ANOVA menunjukkan terdapat perbedaan yang bermakna pada kelompok K3K4-K5 serta K4-K5-K6 ( $p=0.00)$. Hasil uji $t$ menunjukkan adanya perbedaan yang tidak bermakna antarkelompok K1- K2, pada daerah tekanan dan tarikan.

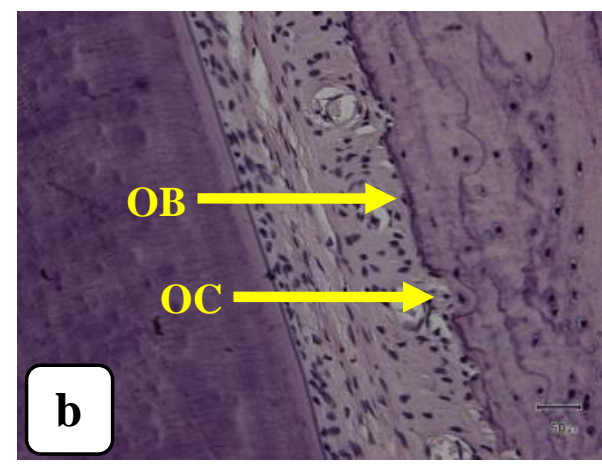

Gambar 2. Gambaran Histologis Sel Osteoblas (OB) dan Osteoklas (OC) Tulang Alveolar di Daerah Tekanan (a) serta Tarikan (b) Ligamen Periodontal. 

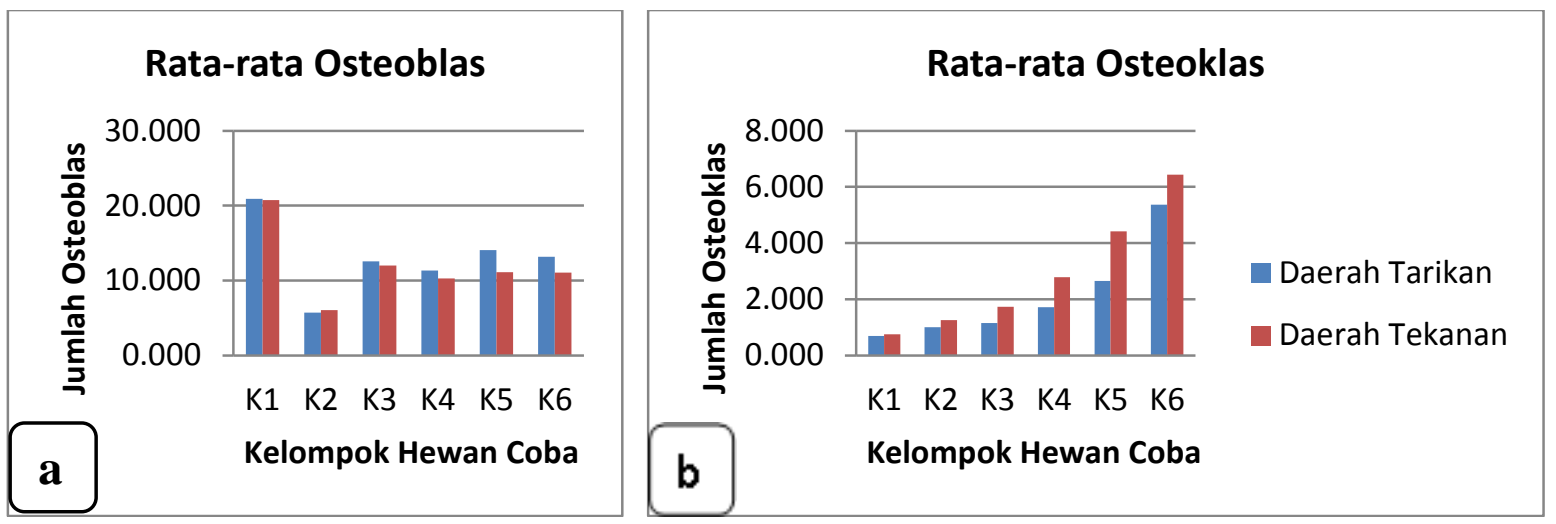

Gambar 3.Diagram Rata-rata Jumlah Osteoblas (a) dan Osteoklas (b) Tulang Alveolar pada Daerah Tekanan dan Tarikan Ligamen Periodontal. Garis merah menunjukkan daerah tekanan, garis biru menunjukkan daerah tarikan. K1 (kontrol negatif, normal, tidak memakai alat ortodonti), K2 (kontrol positif diabetes awal, tidak memakai alat ortodonti), K3 (kontrol positif, normal, memakai alat ortodonti 30 grf), K4 (kondisi diabetes awal, memakai alat ortodonti gaya 10 grf), K5 (kondisi diabetes awal, memakai alat ortodonti gaya 20 grf), K6 (kondisi diabetes awal, memakai alat ortodonti gaya 30 grf).

\section{PEMBAHASAN}

Sel osteoblas dan osteoklas merupakan komponen utama yang berperan pada proses remodeling tulang alveolar. Osteoblas berperan sebagai pembentukan tulang baru, sedangkan osteoklas berperan pada proses resorpsi tulang (Hill, 1998). Aplikasi gaya ortodonti akan menghasilkan pergerakan gigi, yang akan menyebabkan resorpsi tulang alveolar pada daerah tekanan di ligamen periodontal, sedangkan daerah tarikan pada ligamen periodontal mengalami pembentukan tulang alveolar (Roberts-Harry dan Sandy, 2004).

Rata-rata jumlah osteoblas pada daerah tarikan lebih banyak dibandingkan daerah tekanan, sedangkan rata-rata jumlah osteoklas terlihat lebih banyak di daerah tekanan. Hasil tersebut menunjukkan bahwa osteoblas banyak terdapat pada daerah tarikan yang merupakan daerah pembentukan tulang baru, sedangkan osteoklas banyak terdapat pada daerah tekanan yang merupakan daerah resorpsi tulang alveolar.

Hasil analisis rata-rata jumlah osteoblas menunjukkan bahwa pada kondisi diabetes dan semakin besar gaya yang diberikan, akan menyebabkan penurunan jumlah osteoblasnya. Sel osteoblas pada diabetes mengalami apoptosis oleh karena aktivitas AGEs dan ROS. Aktivitas apoptosis pada diabetes berlangsung sangat cepat, bahkan dalam hitungan jam yang disebabkan oleh aktivasi efektor caspase (Graves et al.,
2007). Tingginya tingkat apoptosis pada diabetes disebabkan oleh mediator inflamasi seperti TNF $\alpha$ dan AGEs. ROS juga merupakan penyebab utama dari apoptosis pada diabetes (Hock et al., 2001 dan Alikhani et al., 2005). Peningkatan apoptosis bone lining cells dapat menurunkan tingkat pembentukan tulang baru (Weinstein et al., 1998 dan Hock et al., 2001).

Hasil analisis rata-rata jumlah osteoklas menunjukkan bahwa kondisi diabetes terjadi aktivitas resorbsi tulang yang lebih tinggi, dan akan meningkat aktivitas resorpsinya ketika diaplikasikan gaya ortodonti sebesar 30 grf. Hasil penelitian ini sesuai dengan dengan penelitian terdahulu, dimana terjadi peningkatan profil osteoklas setelah aplikasi gaya ortodonti pada tikus diabetes pada hari ketujuh dibandingkan dengan tikus normal (Liu et al., 2006). Tikus diabetes menunjukkan tingginya derajat inflamasi dan respon inflamasinya akan berlanjut ketika diaplikasikan gaya mekanis sehingga dapat menginduksi keparahan penyakit periodontal (Liu et al., 2006). Hal ini mengakibatkan pembentukan dan aktivitas osteoklas yang lebih lanjut serta hilangnya perlekatan antara tulang dan gigi yang akan menyebabkan peningkatan produksi matriks metalloproteinase, dan gangguan pembentukan tulang baru (Ryan et al., 1999 dan Liu et al., 2006).

Kondisi diabetes berkaitan dengan peningkatan ekspresi beberapa sitokin yang 
berperan pada proses osteoclastogenesis. Pada kondisi diabetes yang disertai periodontitis kronis terjadi peningkatan mediator mediator inflamasi seperti peningkatan ekspresi $\mathrm{TNF} \alpha$, IL-1 $\beta$, IL-6, RANKL dan OPG (Taylor et al., 2013). TNF $\alpha$ dan IL-1 $\beta$ dapat menyebabkan osteoblas mengekspresikan protein RANKL, yang selanjutnya akan menstimulasi prekursor osteoklas untuk berdiferensiasi dan secara langsung mengakibatkan kerusakan tulang alveolar (Cohen, 2008). RANKL juga bertanggung jawab terhadap produksi ROS yang meliputi pembentukan radikal bebas, ion oksigen dan peroksidase, yang merupakan penyebab utama proses osteoclastogenesis (Kim et al., 2010 dan Jules et al., 2012).

Kesimpulan penelitian ini adalah terjadi peningkatan jumlah osteoklas pada kondisi diabetes tahap awal dan akan meningkat seiring peningkatan gaya ortodonti, baik pada daerah tekanan maupun tarikan. Profil osteoblas menunjukkan terjadinya penurunan pada kondisi diabetes tahap awal, namun meningkat kembali seiring peningkatan gaya ortodonti pada kondisi diabetes awal.

\section{DAFTAR PUSTAKA}

Roberts-Harry D,dan Sandy J., 2004. Orthodontics Part 11: Orthodontic Tooth Movement. British Dental Journal196 (7): 391-394

Wongdee K, dan Charoenphandhu N., 2011. Osteoporosis in Diabetes Mellitus: Possible Cellular and Molecular Mechanisms. World Journal of Diabetes2(3): 41-48.

Meikle MC., 2006. The Tissue, Cellular, and Molecular Regulation of Orthodontic Tooth Movement: 100 Years after Carl Sandstedt. European Journal of Orthodontics28: 221-240.

Verna C, Dalstra M, dan Melsen B., 2000. The Rate and the Type of Orthodontic Tooth Movement is Influenced by Bone Turnover in a Rat Model. European Journal of Orthodhontics 22: 343-352.

Reichert C, Deschner J, dan Ja"ger A., 2009. Influence of Diabetes Mellitus on the Development and Treatment of Malocclusions - a Case Report with Literature Review. Journal of Orofacial Orthopedics70:160-175.

Rakel A, Sheehy O, Rahme E, dan Lelorier J., 2008. Osteoporosis among Patients with Type 1 and Type 2 Diabetes. Diabetes\& Metabolism Journal34: 193-205.

Lappin DF, Eapen B, Robertson D, Young J, dan Hodge PJ., 2009. Markers of Bone Destruction and Formation and Periodontitis in Type 1 Diabetes Mellitus. Jounal of Clinical Periodontology36: 634-641.

He H, Liu R, Desta T, Leone C, Gerstenfeld L, dan Graves D., 2004. Diabetes Causes Decreased Osteoclastogenesis, Reduced Bone Formation, and Enhanced Apoptosis of Osteoblastic Cells in Bacteria Stimulated Bone Loss. Endocrinology 145: 447-452.

Liu R, Bal HS, Desta T, Krothapalli N, Alyassi M, Luan Q, dan Graves DT., 2006. Diabetes Enhances Periodontal Bone Loss through Enhanced Resorption and Diminished Bone Formation. Journal of Dental Research85: 510-514.

Graves DT, Liu R dan Oates TW. 2007. Diabetes-Enhanced Inflammation and Apoptosis - Impact on Periodontal Pathosis. Periodontology 200045: 128-137.

Nurdiana, Permatasari N, Setyawati dan Ali M., 1998. Efek Streptozotocin Sebagai Bahan Diabetogenik pada Tikus Wistar dengan Cara Pemberian Intraperitoneal dan Intravena. Majalah Kedokteran Unibraw14(2): 66-73.

Maulana M, Hikmah N, Shita ADP, Permatasari N, dan Widyarti S., 2014. The Effect of Different Orthodontic Force on MMP 9 Expression in a Rat Diabetic Model. The Journal of Tropical Life Science 4(2): 89-95.

Hill PA., 1998. Bone Remodelling. British Journal of Orthodontics 25: 101-107.

Hock JM, Krishnan V, Onyia JE, Bidwell JP, Milas J, dan Stanislaus D., 2001. Osteoblast apoptosis and bone turnover. Journal of Bone and Mineral Research 16:975-984.

Alikhani M, Alikhani Z, dan Graves D., 2005. FOXO1 Functions as A Master Switch that Regulates Gene Expression Necessary for TNF-Induced Fibroblast Apoptosis. The Journal of Biological Chemistry280: 12096-12102.

Weinstein R, Jilka R, Parfitt A, dan Manolagas S.,1998. Inhibition 
osteoblastogenesis and promotion of apoptosis of osteoblasts and osteocytes by glucocorticoids. Potential mechanisms of their deleterious effects of bone. The Journal of Clinical Investigation 102:274-282.

Ryan ME, Ramamurthy NS, Sorsa T, dan Golub LM., 1999. MMP-mediated events in diabetes. Annals of The New York Academy of Sciences 878:311334.

Taylor JJ, Preshaw PM, dan Lalla E., 2013. A Review of The Evidence for Pathogenic Mechanisms that May Link Periodontitis and Diabetes. Journal of Periodontology84(4 Suppl):S113-S134.

Cohen DL.,2008. Inflammation and Bone Loss in Periodontal Disease. Journal of Periodontology79(8 Suppl):15691576.

Kim MS, Yang YM, Son A, Tian YS, Lee SI, Kang SW, Muallem S, dan Shin DM., 2010. RANKL-Mediated Reactive Oxygen Species Pathway that Induces Long Lasting $\mathrm{Ca} 2+$ Oscillations Essential for Osteoclastogenesis. The Journal of Biological Chemistry285: 6913-6921.

Jules J, Zhang P, Ashley JW, Wei S, Shi Z, Liu J, Michalek SM, dan Feng X., 2012. Molecular Basis of Requirement of Receptor Activator of Nuclear Factor $\mathrm{Kb}$ Signaling for Interleukin 1Mediated Osteoclastogenesis. The Journal of Biological Chemistry287: 15728-15738. 